\title{
PENDIDIKAN AKHLAK MULIA PADA SEKOLAH MENENGAH PERTAMA BINA ANAK SOLEH TUBAN
}

\author{
Arif Unwanullah, Darmiyati Zuchdi \\ Universitas PGRI Ronggolawe Tuban, Universitas Negeri Yogyakarta \\ arifunwanullah@yahoo.com
}

\begin{abstract}
Abstrak
Pendidikan akhlak mulia selama ini lebih menekankan pada aspek pengetahuan dari pada aspek sikap dan aplikasinya. Fenomena tawuran pelajar dan pergaulan bebas menjadi bukti. Sekolah Islam berasrama dengan kurikulum khasnya dianggap berhasil mengelola pendidikan karakter akhlak mulia. Namun belum semua sekolah maтри mengelolanya secara efektif. Penelitian ini bertujuan mengetahui dan menggali data mengenai bagaimana perencanaan, implementasi, evaluasi, dan pengelolaan asrama (boarding school system) pendidikan akhlak mulia dilakukan. Penelitian menggunakan pendekatan kualitatif, merupakan studi kasus SMP BAS school boarding sistem Tuban. Temuan penelitian menunjukkan bahwa sekolah melakukan perencanaan program diawali dengan penetapan visi dan misi, tujuan, standart kelulusan, menyusun kurikulum terpadu mengintegrasikan antara kurikulum nasional dan kurikulum khas pondok pesantren dengan penekanan pada pendidikan akhlak mulia. evaluasi dilakukan terus menerus terhadap seluruh aspek kegiatan siswa. Keberhasilan ditandai adanya perubahan perilaku siswa seperti disiplin, rajin ibadah, taat, jujur, dan berprestasi. Masyarakat makin percaya dan lembaga makin berkembang. Salah satu rekomendasi penelitian agar semua pemangku kepentingan komitmen terhadap rencana, menjadi contoh dan melakukan pembinaan terus menerus serta menjalin kemitraan.
\end{abstract}

Kata kunci: pengelolaan, pendidikan, akhlak mulia

\section{GOOD MANNERS EDUCATION AT YUNIOR HIGH SCHOOL TUBAN}

Arif Unwanullah, Darmiyati Zuchdi

Universitas PGRI Ronggolawe Tuban, Universitas Negeri Yogyakarta arifunwanullah@yahoo.com

\begin{abstract}
Good manner education tends to emphasize on knowledge but weak on attitude and its application. The phenomenon of students do juvenile delinquency, promiscuity, and abuse of drugs. Islamic boarding schools with integrating curriculum of national and local /manhaj tarbiyah emphasizes on Islamic religion subjects and good manner values to students. However, many schools have not succeded in managing good manner education yet. This study is aimed to know and find out data about planning, implementation, evaluation, and management school boarding of good manner eduction as a case study of qualitative research in SMP BAS school boarding system Tuban. The study finds that the planning program is formulated in school vision and mission, gol, standart graduation, develop integrated curriculum, and actualizes in active learning process, develop students' extra activity, religious habit and leadership. Evaluation conducted on whole activities continuously. The success of managerial implementation has been indicated by students' attitude changes such as disciplinary, obedience, learning achievement, and less violence. For making effective good manner education program should involve of parents community, togetherness and commitment.
\end{abstract}

Keywords: managing, good manner, islamic based 


\section{PENDAHULUAN}

Kemajuan ilmu pengetahuan dan teknologi yang pesat telah membawa pengaruh yang sangat besar pada hampir semua lini kehidupan baik sosial, politik, ekonomi, maupun pendidikan. Berbagai manfaat telah dapat dirasakan, misalnya kecepatan, keakuratan dan peningkatan kualitas hidup bagi manusia. Isu-isu pokok dalam pengembangan pendidikan di Indonesia yang akhir-akhir terjadi adalah masalah rendahnya kualitas pendidikan dan sumber daya manusia. Tantangan ke depan semakin kompleks dan beragam, dari masalah krisis ekonomi, krisis budaya, krisis moral, sampai pada krisis karakter atau krisis akhlak. Perubahan nilai dan tatanan hidup yang terjadi pada individu maupun sosial adalah fenomena penyimpangan perilaku dan distorsi nilai kemanusiaan, terutama di kalangan remaja, sebagian melakukan pelanggaran nilai agama, budaya, sosial, tawuran, penyalahgunaan obat-obat terlarang, pergaulan bebas, tidak disiplin, kurang empati, berbahasa tidak santun, dan penyimpangan perilaku lainnya perlu penyelesaian dengan bijaksana sehingga tidak menimbulkan kerusakan jiwa dan raga dalam berbangsa dan bernegara.

Kontribusi pendidikan dalam membentuk pribadi dan budaya manusia sangatlah besar. Pola prilaku, dan pola pikir manusia dalam kehidupan sehari-hari tentu tidak lepas dari peran pendidikan. Kualitas suatu bangsa sangat tergantung dari kualitas pendidikannya, pendidikan yang baik akan menghasilkan sumber daya manusia yang baik. Bangsa yang mengelola pendidikan yang baik akan berhasil mengelola sumber daya manusia dengan baik. Idealitas pendidikan yang dicanangkan, ditetapkan, dan diprogramkan dalam tujuan pendidikan masih banyak yang belum direalisasikan, sehingga masih terjadi kesenjangan antara idealitas dengan realitas. Pengetahuan dan nilai-nilai diartikan sebagai obyek pemilikan sehingga ada keterpisahan antara pengetahuan dan nilai-nilai dengan manusia. Pengetahuan siswa tidak seluruhnya bersifat kognitif, namun juga aspek afektif dan psikomotorik. Praktek pendidikan lebih banyak mengembangkan aspek kognitif daripada aspek yang lain.

Praktek pendidikan lebih banyak berpusat pada guru dan kurang memberi porsi pada siswa untuk aktif, guru cenderung seba- gai penguasa kelas sehingga siswa terampas hak-haknya akibat lebih jauh siswa menjadi pasif. Peserta didik secara sempit dipandang sebagai agen pembangunan yang harus dipersiapkan untuk masuk pada tahapan berikutnya untuk memasuki dunia kerja. Siswa tidak dipandang sebagai pribadi utuh yang memiliki potensi untuk berkembang, berjiwa, rasa, karsa, sosial, moral dan budaya. Akibatnya pendidikan lebih cenderung melakukan pendekatan pengembangan aspek intelektual dan kognitif saja, kurang mengembangkan aspek yang lain seperti, aspek sosial, moral, emosional maupun spiritual.

Proses pendidikan yang memerlukan perhatian adalah pemahaman pada peserta didik, yaitu kekhasan dan keunikan pengajaran masih berorientasi materi tektual kurang memperhatikan kontek, sehingga materi berorientasi pada ujian baik semester maupun ujian akhir, pendidikan terbatas pada ruang kelas sehingga siswa terasing dari kehidupan sosial, kebuutuhan siswa terabaikan karena aturan, program, tujuan, dan kebutuhan siswa lainnya ditentukan secara top down tanpa memperhatikan kepentingan siswa, sehingga penyadaran, partisipasi dan pengembangan sikap dan kepribadian kurang diperhatikan.

Secara fungsional, pendidikan pada dasarnya ditujukan untuk menyiapkan manusia menghadapi masa depan agar hidup lebih sejahtera, baik sebagai individu maupun secara kolektif sebagai warga masyarakat, bangsa maupun antar bangsa. Bagi pemeluk agama, masa depan mencakup kehidupan di dunia dan pandangan tentang kehidupan hari kemudian yang bahagia (Umaedi, 2004, p. 1). Persoalan strategi dan pendekatan dalam pengajaran untuk membangun kesadaran nilai kadang juga terkendala masalah ragam etnis, agama dan ras atau antar golongan, misalnya kapan memulai pendidikan nilai tentu sesuai dengan perkembangan dan kematangan intelektualnya, dan kadang materi pen gajaran nilai pemahamannya beragam pada kepercayaan dan agama yang berbeda contoh masalah keimanan, akidah maupun cara beribadahnya, sehingga pengajarannya hanya bersifat diskusi, menemukan dan mengembangkan nilai kemanusiaan yang bersifat umum yang sifatnya hanya verbalisme.

Pendidikan yang menekankan pengembangan moral, budi pekerti, prilaku dan akhlak mulia dirasa sangat dibutuhkan dalam 
kehidupan yang serba modern dan sekuler yang mengarah pada pertentangan dan perebutan materi, sehingga pengembangan aturan dan norma baik dapat berkembang dalam masyarakat. Modernisasi yang berlangsung dalam realitas menimbulkan degradasi keyakinan sehingga nilai-nilai agama menjadi loggar, kehidupan masyarakat menjadi semakin bebas, kontrol sosial menjadi lemah, sumber nilai tidak hanya berasal dari norma dan agama yang ada di masyarakat tetapi bergeser pada logika dan nilai keilmuan yang obyektif dan prakmatis. Lembaga-lembaga sosial seperti pesantren, majlis taklim, lembaga tahfis alquran, rumah zakat dan lain-lain telah menunjukkan perkembangan yang cukup positif namun belum cukup menjadi pusat kehidupan beragama, berbangsa dan bernegara. Pelanggaran norma, kehidupan yang semakin bebas, korupsi yang merajalela, pelanggaran-pelanggaran lain yang terjadi di masyarakat menunjukkan tren yang semakin meningkat sehinga diperlukan formulasi yang lebih akurat dalam menyelesaikan dan menangkal perkembangannya.

Permasalahan pendidikan tidak akan pernah tuntas dalam penyelesaiannya, berbagai fenomena dan permasalahan menjadi keprihatinan dalam dunia pendidikan, proses dan output tidak sesuai harapan, banyak terjadi pelanggaran moral, ketidak adilan dan kejujuran. Praktek pendidikan yang terjadi seharusnya mampu membangun potensi, kepribadian dan ketangguhan. Namun demikian, mutu pendidikan di Indonesia menurut pendapat sebagian pengamat pendidikan tidak meningkat, bahkan cenderung menurun. Salah satu indikatornya adalah menurunnya sikap dan perilaku moral para lulusan pendidikan yang semakin hari cenderung semakin jauh dari tatanan nilai-nilai moral yang dikehendaki (Marzuki, 2009, p. 2).

Pendidikan akhlak adalah pendidikan mengenai dasar-dasar moral (akhlak) dan keutamaan perangai, tabiat yang dimiliki dan harus dijadikan kebiasaan oleh anak sejak kanak-kanak hingga ia menjadi mukallaf. Tidak diragukan bahwa keutamaan-keutamaan moral, perangai dan tabiat merupakan salah satu buah iman yang mendalam, dan perkembangan religius yang benar (Ulwan, 1990, p. 174) sehingga menjadi manusia sempurna (insan kamil). Pemahaman agama yang kuat akan menjadikan manusia bijaksana dan praktik ibadah yang benar akan menjadikan manu- sia sempurna akhlaknya. Secara individu menjadi pribadi yang memiliki nilai-nilai akhlak yang baik dan secara sosial akan melahirkan kehidupan yang harmonis antar warga masyarakat dengan diliputi suasana keakraban, ketertiban, saling membina kebaikan, dan ketentraman. Kehidupan bersama diperlukan suasana saling memahami dan toleransi sehingga tercipta suasana tertib, nyaman, tenang, dan damai.

Kompleksitas permasalahan dalam menanamkan nilai-nilai akhlak, peningkatan kualitas pribadi, memperkuat watak dan karakter baik individu maupun masyarakat menghadapkan manusia Indonesia pada berbagai dilema yang saling berhubungan dan memerlukan pemecahan dengan segera. Tiga pilar pendidikan yaitu sekolah, keluarga, dan masyarakat, mengalami ketidak-harmonisan dalam memecahkan persoalan tersebut. Akibat lebih jauh yaitu adanya berbagai masalah seperti pelanggaran hak asasi manusia, fenomena kekerasan, rusaknya lingkungan hidup, runtuhnya perdamaian dunia, penyalahgunaan narkotika, dan berbagai masalah lainnya yang kesemuanya memerlukan kerja sama berbagai pihak dalam menciptakan kualitas bangsa dan negara Indonesia.

Krisis moral atau permasalahan akhlak yang dialami bangsa khususnya yang melanda para remaja dewasa ini memerlukan penanganan serius. Oleh karena itu, pendidikan dalam semua aspek kehidupan harus dilakukan dalam rangka membentuk kepribadian luhur sesuai budaya bangsa Indonesia, antara lain; taat menjalankan agamanya, jujur, disiplin, toleran, tidak cepat putus asa, bekerja/belajar keras, suka menolong, dan berperilaku baik lainnya. Terkait dengan ini, M. Athiyah al-Abrasyi mengatakan bahwa inti pendidikan Islam adalah pendidikan budi pekerti (akhlak). Jadi, pendidikan budi pekerti (akhlak) adalah jiwa pendidikan dalam Islam. Mencapai akhlak mulia (al-akhlaq al-karimah) adalah tujuan sebenarnya dari pendidikan Islam. Di samping membutuhkan kekuatan dalam hal jasmani, akal, dan ilmu, peserta didik juga membutuhkan pendidikan budi pekerti, perasaan, kemauan, cita rasa, dan kepribadian (Al-Abrasyi, 2003, p. 1).

Dasar yuridis amanat untuk mewujudkan akhlak mulia di bidang pendidikan ditetapkan dalam Undang-undang Dasar Negara Republik Indonesia Tahun 1945 Pasal 
31, dan ayat 3. hasil amandemen (Republik Indonesia, 1945), disebutkan bahwa "pemerintah mengusahakan dan menyelenggarakan satu sistem pendidikan nasional yang meningkatkan keimanan dan ketakwaan serta akhlak mulia dalam rangka mencerdaskan kehidupan bangsa". Hal ini sebagai salah satu landasan untuk menentukan arah pembangunan pendidikan di Indonesia, yaitu pendidikan yang tidak hanya sekedar menghasilkan manusia yang cerdas intelektualnya saja, melainkan juga harus cerdas emosi, dan cerdas spiritual.

Berbicara tentang pengembangan nilai-nilai akhlak mulia, khususnya di tingkat persekolahan, tentu tidak luput dari proses pembinaan yang berkelanjutan. Masalah akhlak tidaklah cukup hanya berupa visi di atas kertas, dan akhlak mulia dalam bentuk tatanan moral di sekolah dan di masyarakat juga tidak mungkin dapat terwujud hanya melalui sarana dan media fisik yang mensosialisasikannya semata, melainkan perlu adanya penunjang, berupa komponen-komponen pendidikan, antara lain: adanya tujuan, materi, kurikulum, metode, dan evaluasinya.

Perkembangan dan kemajuan suatu daerah tidak terlepas dari lingkungan dan latar belakang sejarah yang mengikutinya. Demikian juga kemajuan dan pembangunan Kota Tuban memiliki berbagai permasalahan dan tantangan, terutama perkembangan industri yang pesat berdampak pada perkembangan pendidikan, sosial, budaya, ekonomi, politik, komunikasi, pemerintahan, dan kemajuan daerah, sehingga diperlukan kebijakan dan kearifan dalam perencanaan, pelaksanaan, monitoring, dan evaluasi pengembangannya.

Berdirinya bermacam-macam lembaga pendidikan di Tuban diharapkan menjadi semangat dan keinginan yang berkelanjutan, sehingga pada akhirnya kemajuan peradaban dan kesejahteraan dapat terwujud. SMP BAS (Bina Anak Soleh) Tuban dengan sistem Boarding school berdiri dengan tujuan untuk meningkatkan kualitas pendidikan dengan mengintegrasikan secara integral dan holistik sistem pendidikan umum dan sistem pendidikan religius dalam satu wadah dengan harapan dapat terbagun generasi kepemimpinan yang cerdas pikiran, cerdas hati dan cerdas amal, dengan pengembangan dan peningkatan potensi peserta didik secara komprehensif melalui pengembangan, yang diaplikasikan baik dalam pembelajaran di sekolah, asrama, maupun budaya kehidupan sehari-hari, dengan harapan mampu mencetak calon pemimpin yang berkepribadian muslim dan berprestasi optimal sesuai motto "Clear Head, Clear Heart and Skill Hand”'(Munzir, 2012, p. xiii).

SMP Bina Anak Soleh berdiri sejak tahun 2012, membangun sekolah hingga mampu mendapat kepercayaan masyarakat tidaklah mudah. Berbagai perbaikan dan peningkatan yang telah dilakukan mulai dari sarana, pembinaan guru, kurikulum, dan manajemen sekolah diharapkan dapat lebih meningkatkan kepercayaan masyarakat. Kurikulum ma'had menekankan pada penanaman dan pembiasaan nilai-nilai Alquran. Pendidikan tahfid Quran (minimal 5 juz), Pembelajaran kitab kuning, pembelajaran dan pembiasaan berbahasa Arab dan Inggris, pembelajaran terbimbing. Sementara untuk pembelajaran reguler menggunakan Kurikulum 2013. Guru-guru SMP BAS Tuban sudah mendapatkan pelatihan baik dari diknas maupun yayasan yang kerjasama dengan UNESA (Universitas Negeri Surabaya).

SMP BAS Tuban sebagai sekolah dengan boarding school yang memiliki visi berkepribadian muslim dan berprestasi optimal, berkembang dengan berbagai perbaikan dan peningkatan mulai dari sarana, pembinaan guru, kurikulum, dan manajemen sekolah. Selain pembinaan dalam bidang akademik juga ada pembinaan spritual, kepribadian siswa, dan mewajibkan semua siswa setelah belajar di sekolah untuk tinggal di asrama. Dengan berdasarkan latar belakang dan uraian tersebut di atas, maka penelitian ini mengambil judul: "Pendidikan Akhlak Mulia pada Sekolah Menengah Pertama Bina Anak Soleh Tuban", guna mengungkap proses, hasil yang telah dicapai, dan karakteristiknya.

\section{METODE PENELITIAN}

Penelitian ini adalah penelitain kualitatif dengan paradigma naturalistik. Fokus penelitian ini adalah pengkajian perencanaan, implementasi, evaluasi, dan pengelolaan boarding school dalam mendidik dan membimbing akhlak mulia siswa SMP BAS Tuban. Sumber data dan informan adalah kepala sekolah, wakil kepala sekolah, guru kelas, karyawan, siswa, dan orang tua siswa SMP BAS Tuban. Semua informan merupakan sumber data primer untuk digali secara mendalam untuk mengkaji pendidikan akhlak mulia di SMP BAS Tuban. 
Pengumpulan data dilakukan dengan teknik observasi, wawancara mendalam, dan dokumentasi. Penelitian ini menggunakan dua model analisis, yaitu analisis saat mempertajam keabsahan data dengan trianggulasi dan analisis data melalui interpretasi. Ada empat tahap dalam analisis yang sangat berkaitan, yaitu: pengumpulan data, reduksi data, penyajian data, dan penarikan kesimpulan atau verifikasi.

\section{HASIL PENELITIAN DAN PEMBAHASAN}

Perencanaan Pendidikan Akhlak Mulia di SMP BAS Tuban, dilakukan dengan meliputi sebagai berikut. Pertama, Penetapan Visi SMP BAS Tuban: Membentuk anak berkepribadian muslim dan berprestasi optimal, telah memenuhi persaratan sebagai dikemukakan oleh Bryson (2001, p. 2013) antara lain: (a) Visi harus dapat memberikan panduan/ arahan dan motivasi; (b) Visi harus disebarkan di kalangan anggota organisasi (stakeholder); c) Visi harus digunakan untuk menyebarluaskan keputusan dan tindakan organisasi yang penting.

Kedua, Perumusan misi yang dituangkan dalam dalam RPS merupakan pernyataan mengenai hal-hal yang harus dicapai organisasi sebagaimana Akdon (2006, p. 97) menyataan bahwa misi adalah pernyataan mengenai hal-hal yang harus dicapai organisasi bagi pihak-pihak yang berkepentingan di masa datang dan mencerminkan tentang penjelasan pelayanan yang ditawarkan;

Ketiga, menentukan Tujuan kegiatan SMP BAS Tuban sudah menunjukkan kondisi yang ingin dicapai di masa mendatang (Akdon, 2006, p. 143). Tujuan akan mengarahkan perumusan sasaran, kebijaksanaan, program dan kegiatan dalam rangka merealisasikan misi, oleh karena itu tujuan harus dapat menyediakan dasar yang kuat untuk menetapkan indikator. Program operasional yang telah dijadwalkan oleh SMP BAS Tuban berisi kumpulan kegiatan yang dihimpun dalam satu kelompok kegiatan untuk mencapai tujuan dan sasaran sesuai pendapat (Akdon, 2006, p. 135). Program merupakan kumpulan kegiatan nyata, sistematis dan terpadu, dilaksanakan oleh satu instansi pemerintah atau lebih ataupun dalam rangka kerja sama dengan masyarakat atau yang merupakan partisipasi aktif masyarakat guna mencapai tujuan dan sasaran yang telah ditetapkan.

\section{Implementasi Pendidikan Akhlak Mulia di SMP BAS Tuban}

Fokus pengembangan terutama pada: Nilai-nilai Pendidikan Akhlak terhadap Allah. Sebagai makhluk tentu saja manusia hanya ada kewajiban beribadah kepada Allah. Dalam hubungannya dengan pendidikan akhlak nilainilai yang perlu ditanamkan adalah: (a) taat terhadap perintah Allah, dengan mempelajari hukun dan jenis-jenis perbuatan yang diperintahkan dan dilarang; (b) tawakkal hanya kepada Allah, baik ucapan maupun perbuatan; (c) memiliki rasa tanggung jawab atas samanah, berupa syariat yang wajib dijalankan secara bertanggung jawaban; (d) rida terhadap ketentuan Allah Swt., sehingga selalu bersyukur, bersabar, dan tawakkal; (e) senantiasa bertaubat kepada-Nya; (f) penanaman konsep agar obsesinya adalah keridaan Illahi; (g) merealisasikan ibadah kepada-Nya; (h) banyak membaca Alquran, sebagai konsekuensi rasa cinta pada Allah Swt.

Bentuk kegiatan yang dilaksanakan secara praktis adalah: (a) salat Berjamaah; (b) salat sunah qabliyyah dan bakdiyyah; (c) tahfidz Alquran; (d) kegiatan bulan Ramadan; (e) Isra' Mi'raj Nabi Muhammad saw; (f) Nuzulul Quran; (g) hari raya idul ftri; (h) hari raya Idul Adha; (i). tahun baru hijriyah; (j). 10 Muharram; (k) ikhlas yaitu tindakan yang dilakukan tanpa pamrih; (1) rendah hati (tawadhu') yaitu berperilaku yang mencerminkan sifat yang tidak sombong. Hasil ini sesuai dengan beberapa penelitian yang dilakukan oleh Marzuki (2011) tentang Model Pembentukan Kultur Akhlak Mulia Siswa Smp Di Indonesia. Dengan hasil bahwa nilai-nilai akhlak yang dipraktekkan dan diprogramkan secara rutin dan secara insidentil yang akhirnya menjadi kultur dan membentuk akhlak mulia siswa.

Nilai-nilai Akhlak kepada Nabi Muhammad saw. merupakan salah satu keyakinan (iman) dalam Islam. Berbagai cara yang dapat dilakukan untuk berakhlak kepada Nabi Muhammad saw. adalah mencintai dan memuliakannya, patuh kepadanya, serta mengucapkan salawat dan salam, Kehadiran Rasulullah adalah untuk membimbing umat manusia supaya berada dalam jalan yang benar yang dikehendaki Allah dan Rasulnya, memiliki akhlak mulia dan sopan santun yang mempertinggi jiwa. Rasul juga berupaya menetapkan 
hukum-hukum dan segala peraturan yang harus diikuti oleh manusia selama hidupnya (Rusli \& et al, 1993). Dengan demikian arti beriman kepada nabi dan rasul adalah tidak cukup hanya dengan pengakuan hati dan lisan saja, tetapi harus disertai dengan kesediaan melaksanakan seruannya dalam kenyataan hidup sehari-hari, sehingga manfaatnya lebih terasa lagi wujud dari berakhlak pada nabi diantaranya adalah: a. Beriman pada Nabi; b. Mencintai dan Memuliakan Nabi; c. Taat dan Patuh kepada Nabi (Ilyas, 2014, p. 66).

Meneladani Nabi Muhammad saw. Keteladanan diharapkan dengan bercirikan: (1) Siddiq, yang berarti jujur; (2) Tabligh, yang berarti selalu menyampaikan kepada umat; (3) Amanah, yang berarti dapat dipercaya; (4) Fathanah, yang berarti selalu berpikir jernih (Ilyas, 2014). Beberapa praktek yang dilakukan di asrama SMP BAS Tuban antara lain: (1) menghidupkan sunah, dengan mempelajari hadis, membaca salawat, sirah nabi, dan memahami sejarah para sahabat dll; (2) taat, dengan melaksanakan perintah-perintah-Nya serta menjauhi larangan-laranganNya; (3) memperbanyak membaca salawat dan salam, mendoakan atau memohonkan berkah kepada Allah SWT. untuk Nabi saw. Bentuk kegiatan praktis dalam penanaman nilai-nilai kecintaan kepada Rasulallah adalah: (a) kegiatan salawatan sebelum salat berjamaah; (b) kegiatan Maulid Nabi Muhammad saw, adalah Peringatan Maulid Nabi adalah memperingati hari kelahiran Nabi Muhammad saw.

Nilai-nilai Pendidikan Akhlak terhadap Diri Sendiri. Manusia mempunyai kewajiban kepada dirinya sendiri yang harus ditunaikan untuk memenuhi haknya. Kewajiban ini bukan semata-mata untuk mementingkan dirinya sendiri atau menzalimi dirinya sendiri. Dalam diri manusia mempunyai dua unsur, yakni jasmani (jasad) dan rohani (jiwa). Selain itu manusia juga dikaruniai akal pikiran yang membedakan manusia dengan makhluk Allah yang lainnya. Tiap-tiap unsur memiliki hak di mana antara satu dan yang lainnya mempunyai kewajiban yang harus ditunaikan untuk memenuhi haknya masing-masing (Djatnika, 1996, p. 26). Sedangkan Al Ghozali (Mujib, 2006, p. 387) mengatakan bahwa, setiap diri memiliki tiga macam potensi yaitu nafsu, amarah, dan kecerdasan. Bila dikembangkan secara positif, nafsu dapat menjadi suci, amarah bisa menjadi berani dan kecer- dasan bisa menjadi bijak. Sehubungan dengan hal tersebut di atas seorang anak harus diberi pengertian bahwa pahala dan dosa akan kembali pada diri sendiri sehingga sikap-sikap yang perlu ditanamkan pada diri anak yaitu: a. Menjaga kebersihan diri sendiri. Terdiri dari. 1) Menjaga makan dan minumnya, bersahaja, sederhana, dan bergizi dalam makan minum, dan tidak berlebihan bagian dari moto SMP BAS Tuban; 2) Tidak mengabaikan latihan jasmaninya, Riyadhah atau latihan jasmani amat penting dalam menjaga kesehatan. Kegiatan yang dilaksanakan berupa olah raga, kokurikuler krida (pramuka, PMR, LBB), karate, sepak bila dan LDK; b. Rupa diri, muslimin dan muslimat mestilah mempunyai rupa diri yang baik. Islam tidak pernah mengizinkan budaya tidak senonoh, compang-camping, kusut, dan seumpamanya. Umat Islam adalah agama yang menganjurkan umatnya agar mempunyai rupa diri yang baik; c. Memenuhi akalnya dengan ilmu,. Islam menyuruh supaya membangun potensi akal hingga ke tahap maksimum, salah satu cara memanfaatkan akal ialah mengisinya dengan ilmu. Penguasaan ilmu pengetahuan, Islam mewajibkan umatnya baik laki laki maupun perempuan untuk mencari ilmu, umat. Praktek kegiatan yang diprogramkan dalam menanamkan akhlak pada diri sendiri adalah: 1) Kultum sebelum/setelah salat berjamaah; 2) Bimbingan kosakata Bahasa Arab dan Bahasa Inggris; 3) Pembelajaran Kitab Kuning; 4) Kegiatan Pengembangan Diri dalam LDKS dan OSIS; 5) Tanggung jawab yaitu melaksanakan tugas secara sungguh-sungguh, serta berani menanggung konsekuensi dari sikap, perkataan dan tingkah lakunya; 6) Muhadharah; Teladan langsung dalam membimbing. Nilai praktis yang ditanamkan untuk pendidikan akhlak pada diri sendiri adalah: jujur, disiplin, hemat, pantang menyerah, adil, berpikir positif, mandiri, percaya diri, kreatif atau inisiatif, kerja keras (Marzuki, 2009, pp. 117-213).

Peran Pendidikan Akhlak terhadap lingkungan terdiri dari: Pertama, akhlak terhadap Lingkungan Keluarga. Sikap utama yang harus dikembangkan pada anak dalam keluarga yang utama yaitu penanaman sikap berbakti kepada orang tua yang telah mendidik anakanak dengan penuh kasih sayang (Ilyas, 2014, pp. 147-183). Kedua, lingkungan sekolah merupakan kegiatan untuk menanamkan akhlak 
pada lingkungan sekolah diantaranya adalah: (1) Makan Bersama di Kantin Kejujuran; (2) Santun yaitu menunjukan prilaku interpersonal sesuai tatanan norma dan adat istiadat setempat, (3) Program 5S (Senyum, Salam, Sapa, Sopan, dan Santun). Program 5S ini sudah menjadi budaya seluruh warga SMP Bina Anak Soleh Tuban, Bahkan mulai dari SD pun sudah diterapkan program 5S ini; (4) Lingkungan Masyarakat atau Lingkungan Sekitar (Ilyas, 2014, pp. 195-247).

Bentuk kegiatan yang sering ditanamkan pada siswa-siswi diantaranya, (1) hormat pada sahabat, dan tetangga, memulai salam, merupakan konsep dan tanda rendah hati (tawadhu); (2) bermuka berseri-seri (ceria), senyummu kepada saudaramu adalah sedekah; Bersilaturahmi (saling berkunjung); (3) kasih sayang yaitu kepedulian terhadap makhluk ciptaan Tuhan; (3) Cinta damai yaitu menciptakan dan memelihara perdamaian; (4) Toleransi yaitu kerelaan menerima kenyataan adanya orang lain yang berbeda; (5) Kasih sayang yaitu kepedulian terhadap makhluk ciptaan Tuhan; (6) kerja sama yaitu melakukan kegiatan dengan orang lain untuk mencapai tujuan bersama; (7) kerja bakti penanaman mangruf, Sebagai bentuk kepedulian lingkungan dan mencegah terjadinya abrasi serta penyelamatan ekosistem pesisir pantai di Kabupaten Tuban, SMP BAS Tuban melaksanakan kegiatan menanam Mangrove di kawasan pantai Mangrove Center Tuban,

\section{Pembinaan Akhlak Mulia}

Pembinaan akhlak mulia melalui tahapan kegiatan sebagai berikut. Tahap Persiapan (Rencana Program), Kepala Sekolah bersama Wakil Kepala Sekolah dan para guru pembina kegiatan ekstrakurikuler dengan pihak yayasan menentukan nilai akhlak yang akan dikembangkan dan akan menjadi budaya sekolah, Sebagai contoh, sekolah memilih nilai disiplin sebagai nilai akhlak yang akan dikembangkan menjadi budaya sekolah, Ma$\mathrm{ka}$, semua kegiatan yang dilakukan, mengacu kepada nilai disiplin tersebut. Praktek pembinaan akhlak mulia yang direncanakan dan dibudayakan dalam kehidupan sehari-hari siswa SMP BAS adalah sebagai berikut.

Pertama kedisiplinan, Unsur-unsur yang harus ada dalam disiplin, antara lain: (a) peraturan, berupa pola perilaku yang ditetap- kan yang mengandung nilai pendidikan; (b) pemberian sangsi atau hukuman bagi yang melanggar, Fungsi hukuman adalah untuk menghalangi terulangnya perbuatan; (c) pemberian penghargaan, hadiah atau reword bagi yang melaksanakan; konsisten dalam pelaksanaan, Konsistensi berarti stabilitas atau keseragaman,

Kedua, taat pada tata tertib, Guna mendukung terciptanya suasana yang tertib, aman dan nyaman maka diperlukan aturan atau tata tertib yang mengatur berbagai aspek kehidupan di SMP BAS Tuban hal ini sesuai dengan teori yang dikemukakan oleh (Ilyas, 2014 , p. 103). Berdasarkan hasil wawancara mendalam dan telaah terhadap dokumen yang ada, ternyata sekolah telah melibatkan siswa dalam menetapkan aturan yang harus dilaksanakan oleh siswa. Aturan yang ada disosialisasikan pada saat awal masuk ke sekolah, yakni saat orientasi siswa, Kewajiban dan larangan yang telah ditetapkan oleh sekolah tersebut, selain itu ada kode etik yang telah dirumuskan menyatakan bahwa setiap siswa SMP BAS Tuban wajib untuk: (a) menjalankan ibadah sesuai dengan syariat Islam yang dituntunkan; (b) menghormati pendidik dan tenaga kependidikan; (c) mengikuti prosesa pembelajaran dengan menjunjung tinggi ketentuan pembelajaran dan mematuhi semua peraturan yang berlaku; (d) memelihara kerukunan dan kedamaian untuk mewujudkan harmoni sosial di antara teman; (e) menyintai keluarga, rnasyarakat, dan menyayangi sesama; (f) menyintai lingkungan masyarakat, berbangsa dan bernegara; (g) menjaga dan memelihara sarana dan prasarana, kebersihan, ketertiban; kedisiplinan, keamanan, keindahan, dan kenyamanan sekolah.

Ketiga, kejujuran menjadi salah satu dari lima nilai yang dikembangkan di SMP BAS Tuban. Upaya yang telah dilakukan oleh sekolah dalam menanamkan kejujuran saat ujian antara lain: (a) menekankan kepada siswa untuk kerja mandiri, jujur, percaya pada kemampuannya sendiri; (b) pengawas ujian dilakukan dua orang tiap kelas agar dapat mengawasi siswa secara lebih baik; (c) suasana ujian diciptakan seperti saat ujian nasional, yakni dengan penataan meja, mengunci pintu di luar jam ujian, menyediakan kartu ujian dan kelengkapan lain; (d) pengawas ujian membangun performan seperti saat ujian nasional, seperti penggunaan cocard dan lain-lain; (e) 
siswa menulis komitmen untuk berlaku jujur saat ujian, Komitmen tersebut ditulis di kartu ujian, Cara ini sempat menunjukkan hasil yang baik, walau masih belum optimal; f) siswa menulis pakta integritas tidak hanya dikartu ujian, namun disetiap lembar jawaban,

\section{Tahap Pelaksanaan (Proses)}

Melalui kegiatan KBM, kondisi guru secara umum, melaksanakan proses belajar: (1) Pendekatan Guru dalam Mengajar di Kelas. Berdasarkan hasil pengamatan terhadap proses belajar mengajar di kelas, tampak bahwa secara umum guru memiliki kemahiran dalam mengajar. Dari segi pendidikan, 36 guru sarjana, 3 guru lulus Pascasarjana, Mereka juga telah mengikuti berbagai diklat untuk meningkatkan profesionalitas dalam mengajar, Diklat yang diikuti oleh guru SMP BAS Tuban antara lain: (a) Diklat tingkat dasar dalam mengajar, di Balai Diklat Universitas Negeri Surabaya; (b) Diklat tingkat lanjut, dilaksanakan di Balai Diklat Universitas Negeri Surabaya; (c) Program MGMP tingkat Propinsi Surabaya, yang diselenggarakan minimal satu bulan sekali; (d) Program kegiatan yang dilaksanakan secara insidental oleh Kementerian Pendidikan Dasar dan Menengah, Lembaga perguruan Tinggi, atau lainnya.

2) Pendekatan Guru di Luar kelas. Pendekatan guru terhadap siswa di luar kelas di SMP BAS Tuban santun dan tertib. Hal ini tampak pada kehidupan sehari-hari, sehingga secara individu dan sosial timbul hal-hal sebagai berikut, (a) siswa merasa diterima secara sosial, dihargai, sehingga muncul rasa percaya diri; (b) terbangun sikap peduli dan empati terhadap orang lain; (c) terbangun hubungan kasih sayang, akrab, terbuka, saling menghargai antarsesama; (d) terbangun solidaritas, kerjasama, dan semangat saling membantu antarsesama; e) Siswa dapat mengembangkan kecerdasan intelektual, sosial, dan emosional sebagai satu kesatuan yang holistik dalam batas tertentu.

3) Melalui kegiatan ekstrakurikuler meliputi: (a) Krida, meliputi Kepramukaan, Latihan Dasar Kepemimpinan Siswa (LDKS), Palang Merah Remaja (PMR), Pasukan Pengibar Bendera Pusaka (PASKIBRAKA); (b) Karya Ilmiah, meliputi Kegiatan Ilmiah Remaja (KIR), kegiatan penguasaan keilmuan dan kemampuan akademik, penelitian; (c) Latihan/ lomba keberbakatan/ prestasi, meliputi pengembangan bakat olah raga, seni dan budaya, cinta alam, jurnalistik, teater, keagamaan; (d) Olahraga, yang meliputi beberapa cabang olahraga yang diminati tergantung sekolah tersebut, misalnya: basket, karate, taekwondo, silat, softball, dan lain sebagainya. Dari metode-metode di atas dapat dikatakan bahwa pembinaan akhlak dapat dilakukan dengan berbagai cara sebagaimana dikatakan Mulkan (1994, p. 250), bahwa metode adalah suatu cara yang digunakan untuk menyampaikan atau mentrasfer masikan ilmu atau bahan pendidikan kepada anak didik baik di dalam maupun di luar kelas dalam lingkungan sekolah.

\section{Tahap Evaluasi Implementasi Nilai-nilai Akhlak Mulia di Sekolah}

Strategi program, rencana, dan proses pelaksanan nilai-nilai akhlak mulia sebagaimana tertuang dalam uraian bahasan sebelumnya, maka dalam evaluasi keberhasilan yang perlu diperhatikan, adalah sebagai berikut: (a) keimanan, yaitu pemahaman adanya Tuhan; (b) pengalaman, yaitu kesempatan mempraktekan ibadah dalam menghadapi tugas; (c) pembiasaan, yaitu membiasakan sikap dan prilaku baik; (d) rasional, yaitu memahami dan membedakan perilaku baik buruk; (e) emosional, yaitu upaya menggugah perasaan (emosi) peserta didik; (f) fungsional yaitu materi pokok (Alquran, keimanan, ibadah, fiqih, ahlak); (g) keteladanan, yaitu menjadikan figur guru agama dan non agama serta petugas sekolah yang lainya.

Evaluasi yang diselenggarakan oleh sekolah yaitu dengan menyampaikan melalui catatan kegiatan baik dengan tazkiah (penyucian diri) atau muhasabah (introspeksi diri). Adapun pelaksanaannya adalah sebagi berikut: (1) Tazkiah li an nafs SMP BAS Boarding School Tuban Ibnu jarir ath thobari 1420 H: 454 menafsirkan Q.S. As syams, 9 dan 10. bahwa orang-orang yang beruntung adalah mereka yang Allah sucikan jiwanya dari kekufuran dan kemaksiatan, serta memperbaikinya dengan amal sholeh. Untuk mendapatkan keberuntungan tersebut dari Allah Swt. Katsir (1420H, p. 412) menjelaskan bahwa manusia harus menempuh jalan yaitu mentaati Allah, membersihkan jiwanya dari akhlak tercela serta membersihkan jiwa dari berbagai hal yang hina. Penyelenggaran kegiatan malam bina iman dan takwa (Mabit), sebagai kelan- 
jutan buku panduan program mabit dilaksanakan dalam 3 (tiga) bulan sekali yang diikuti seluruh siswa SMP BAS Tuban dengan kegiatan yang telah ditentukan. Prosesi mabit dan nilai yang terkandung di dalamnya dapat dijelaskan sebagai berikut: (a) Pada pukul 15,30 dilakukan pembagian kelompok yang terdiri 10 orang dan salah satunya mengenal tempat Mabit; (b) menjelang Magrib dilakukan zikir bersama, memiliki nilai: ketaatan, ibadah, kejujuran, dan nilai tazkiah; c) Jamaah salat Magrib dan zikir kemudian dilakukan tazmi' berdasarkan kelompok; d) Salat Isya' berjamaah dilanjutkan zikir bersama; e) Pada pukul 19,45 dilakukan acara mabit dengan pembukaan dan tilawah Alquran; f) Pukul 20,00 sampai 22,00 dilakukakan ceramah dan dialog, Kegiatan tersebut memiliki nilai: ketaatan, kemandirian, toleransi, ibadan dan tanggung jawab; g) Pukul 22,00 semua siswa beristirahat dan tidur di tempat yang disediakan. Kegiatan tersebut memiliki nilai: kemandirian, toleransi, dan tanggung jawab; h) Pada pukul 03,00 sampai 03,45 dilakukan muhasabah dan solat tahajut dipimpin ustad yang bertugas, acara ini berisi refleksi diri. Kegiatan tersebut mengandung nilai: ketaatan, kejujuran, tazkiah (penyucian diri), ibadah, keman-dirian, toleransi, dan tanggung jawab; i) Pada pukul 04,15 dilakukan jamaah salat subuh yang dilanjutkan ma'surat pagi. Kegiatan ini mengandung nilai: ibadah, ketaatan, tazkiah, kejujuran, toleransi, dan tanggung jawab; j) Kemas-kemas yang dilakukan oleh semua siswa, mengandung nilai: kemandirian, toleransi, dan tanggung jawab; k) Bersihbersih masjid dan lingkungan dilakukan bersama-sama; (1) Pulang ke asrama. (2). Muhasabah li an nafs. Evaluasi diri di SMP BAS Tuban juga dilakukan dengan cara lain yaitu berupa kegiatan muhasabah (introspeksi diri). Imam Al-Ghozali (Hadziq, 2005, p. 31) berpendapat bahwa Muhasabah merupakan upaya i'tisham dan istiqomah. I'tisham merupakan pemeliharaan diri dengan berpegang teguh pada aturan-aturan syariat. Sedangkan istiqomah adalah keteguhan diri dalam menangkal berbagai kecenderungan negatif. Dengan muhasabah (mawas diri), selain dapat mendorong orang untuk menyadari kekhilafannya, dapat pula memotivasi orang mendekatkan diri kepada Allah, mendorong kearah hidup bermakna dalam dataran kesehatan mental, dan hidup bermanfaat sebagaimana perilaku manusia sejati yang ciri-cirinya menurut Marcel (tokoh Psikologi Eksistensial) sebagai berikut: (1) memiliki semangat partisipasi, (2) semangat kesiap-siagaan, dan (3) memiliki harapan ke-pada yang mutlak (Hadziq, 2005, pp. 31-32). Setiap satu bulan sekali pada malam minggu setiap akhir bulan, upacara diikuti oleh semua siswa-siswi di lapangan olah raga sekolah. Kegiatan dalam upacara tersebut adalah pela-poran dan pengakuan bagi siswa siswi yang melanggar aturan. Catatan pelanggaran biasanya sudah dimiliki oleh pembina dan sudah dikoordinasikan dengan guru Bimbingan Penyuluhan dan wali kelas. Pada akhir upacara pembina memberikan tausiyah yang berisi tentang penyadaran diri.

\section{Pengelolaan Asrama SMP BAS Tuban}

Keberadaan asrama sekolah mulai diminati dan dicari oleh orang tua siswa yang akan menyekolahkan putra-putrinya tanpa khawatir kebebasan pergaulan dan isu negatif globalisasi dan modernisasi. Pengaruh boarding school menjadikan anak lebih aman untuk tinggal selama 24 jam dengan mendapat pantauan dan bimbingan dari pengasuh asrama sekolah. Strategi yang dilakukan dalam membentuk visi, misi, tujuan, dan standart lulusan dengan mengintegrasikan pendidikan agama dan pendidikan umum

Manajemen menurut istilah adalah proses mengkordinasikan aktifitas-aktifitas kerja sehingga dapat selesai secara efesien dan efektif dengan dan melalui orang lain (Robbins \& Coulter, 2007, p. 8). Dari pengertian manajemen di atas maka dapatlah dikatakan bahwa manajemen merupkan sebuah proses pemanfaatan semua sumber daya melalui bantuan orang lain dan bekerja sama dengannya, agar tujuan bersama bisa dicapai secara efektif, efesien, dan produktip. Sedangkan Pendidikan Islam merupakan proses transinternalisasi nilai-nilai Islam kepada peserta didik sebagai bekal untuk mencapai kebahagiaan dan kesejahteraan di dunia dan di akhirat.

Pengelolaan Asrama SMP BAS Tuban dengan rincian berikut: Pertama, Departementaliasi merupakan pengelompokan kegiatan-kegiatan kerja suatu organisasi agar kegiatan-kegiatan yang sejenis dan saling berhubungan dapat dikerjakan bersama-sama. 
Struktur organisasi disusun bertujuan untuk mengelompokkan pekerjaan sesuai dengan jenis dan fungsi serta tanggung jawab masingmasing. Kedua, pembagian kerja, dalam pengelolaan asrama SMP Bina Anak Soleh Tuban ini adalah rincian tugas pengurus dari masing-masing individu untuk bertanggung jawab dalam melaksanakan tugasnya secara spesifik adalah sebagai berikut, (1) Direktur merupakan pimpinan yang tertinggi yang bertanggung jawab terhadap keberlangsungan dan kemajuan pesantren Bahrul Huda Tuban; (2) Dewan Direktur, Kepala-kepala unit yang ada di SMP BAS Tuban ini masuk pada dewan direksi. Tugasnya adalah bertanggung jawab untuk mengendalikan unit yang dipimpinnya;

(3) Kepala Sekolah, bertanggung jawab pada: (a) Bertanggung jawab terhadap terwujudnya SMP BAS Tuban; (b) Bertanggung jawab terhadap ketercapaian standar mutu; (c) Bertanggung jawab terhadap ketercapaian standar kompetensi lulusan. (4) Tugas wakil kepala sekolah adalah: (a) Pelaksana tugas formal dan nonformal; (b) Mewakili Kepala Sekolah jika berhalangan; (c) Melaksanakan kontrol dan pengendalian kinerja guru/karyawan; (d) Bertanggung jawab terhadap pelaksanann program kerja dan pelaporannya. (5) Kepala Urusan Keasramaan, bertanggung jawab sebagai berikut: (a) Menyusun program pembinaan ruhani dan kepengasuhan; (b) Melaksanakan bimbingan, pengarahan dan pengendalian kegiatan siswa; (c) Membina pengurus orgarisasi siswa; (d) Menyusun program dan jadwal pembinaan siswa secara berkala dan insidentil; (e) Menciptakan suasana asrama secara; kebersihan, ketertiban, kenyamanan, keindahan dan kekeluargaan (5K); (f) Bersama kaur kesiswaan mengadakan pemilihan siswa untuk kegiatan diluar sekolah; (g) Menciptakan lingkungan bahasa Arab dan Inggris di sekolah; (h) Menyelenggarakan pelaksanaan program bimbingan konseling; (i) Menyusun laporan secara berkala.

(6) Kepala urusan adminiatrasi, bertanggung jawab sebagai berikut: (a) Menyusun program kerja; (b) Mengelola keuangan sekolah; (c) Mengurus adminiatrasi ketenagaan dan siswa; (d) Menyusun adminiatrasi perlengkapan sekolah (e) Menyusun dan penyajian data/statiatik sekolah; (f) Merancanakan kebutuhan sarana prasarana; (g) Merenca- nakan,mengatur, mengelola program, sarana prasarana; (h) Menyusun laporan berkala (7) Wali Pengasuh Asrama Sekolah, Tugas dan kewenangan adalah sebagai berikut: (a) Mengantarkan santri agar mampu melaksanakan seluruh aktivitas; (c) Membimbing dan mengarahkan anak dalam mencari jatidiri; (b) Membantu santri dalam memecahkan masalah-masalah pribadi; (c) Membimbing anak agar memiliki akhlak mulia; (d) Membuat rencana program pembinaan santri semesteran/ tahunan; (e) Melaksanakan kegiatan pembinaan dan belajar-mengajar; (f) Menyusun dan melaksanakan program perbaikan; g) Pengelolaan ruang asrama, program $3 \mathrm{~K}$ di kamar; (h) Penyelenggaraan adminiatrasi asrama; (i) Menciptakan suasana kamar yang kondusif untuk belajar dan istirahat; (j) Mengontrol arsip data inventarisasi pribadi, muhasabah harian, lembar pencapaian target mental spiritual siswa; (k) Penyusunan pembuatan statiatik bulanan kondiai siswa; (l) Membuat catatan khusus tentang perkembangan siswa; (m) Pengisian dan pembagian buku laporan penilaian mental spiritual.

(8) Guru Bimbingan dan Konseling, tugas dan kewajiban adalah sebagai berikut: (a) Penyusunan program dan pelaksanaan bimbingan dan koseling; (b) Koordinasi dengan wali kelas dalam rangka mengatasi masalah masalah; (c) Memberikan layanan bimbingan agar lebih berprestasi dalam belajar; (d) Memberikan layanan bimbingan tentang pendidikan lanjutan; (e) Mengadakan penelitian pelaksanaan bimbingan dan konseling; (f) Menyusun statistik hasil penilaian bimbingan dan konseling; (g) Melaksanakan kegiatan analisis hasil evaluasi belajar; (h) Menyusun dan melaksanakan program tindak lanjut bimbingan dan koseling; (i) Menyusun laporan pelaksanaan bimbingan konseling. (9) Pembinaan Siswa di asrama sekolah, tujuan siswa berada di asrama sekolah di SMP Bina Anak Soleh Tuban adalah menciptakan siswa yang unggul dari segi ilmu pengetahuan dan menciptakan lingkungan pendidikan yang integral antara aspek kognitif, afektif, dan psikomotorik dalam suasana Islami, Sehingga pembinaan siswa di asrama sekolah secara optimal harus dilakukan, karena selama 24 jam siswa berada dalam pengawasan sekolah/ madrasah, temuan dalam penelitian adalah sebagai berikut, (a) Pengorganisasian asrama sekolah, dengan kegiatan: (1) Struktur organi- 
sasi asrama disusun secara rinci sesuai dengan kebutuhan lembaga; (2) Dibuat pembagian rincian tugas dan kewenangan; (3) Dilakukan pendampingan terhadap santri selama 24 jam; (4) Dibentuk organisasi siswa asrama beserta bidang kegiatannya; (5) Dilakukan pengelompokan siswa berdasarkan jenjang kelas; (6) Dilakukan pembinaan terhadap siswa selama di asrama. (b) Pendidikan akhlak mulia siswa yang diharapkan, (1) Dilakukan untuk menumbuhkan kebisaaan; (2) Melalui pendampingan dengan harapan tertanam sikap, sadar akan hak, kuwajiban, dan rasa percaya diri; (3) Melalui organisasi siswa terbentuk jiwa kepemimpinan yang tangguh; (4) Melalui organisasi siswa terbentuk siswa yang disiplin dan tanggung jawab; (5) Membentuk pribadi yang tangguh, kerja keras dan mandiri.

\section{SIMPULAN}

Perencanaan program pendidikan akhlak mulia di SMP BAS dilakukan dengan penyusunan rencana strategis yang memuat tentang visi, misi, tujuan, dan standar kelulusan. Muatan kurikulum terintegrasi dalam kurikulum terpadu pendidikan umum dan pendidikan pesantren (keagamkaan). Muatan kurikulum keagamaan dalam bentuk penambahan jam tatap muka atau melalui kegiatan pembinaan/ekstrakurikuler yang menitikberatkan pada pendidikan/ akhlak mulia. Sumber rujukan nilai-nilai inti akhlak mulia berbasis Islam berpedoman pada Alquran dan Hadis.

Implementasi pendidikan akhlak mulia. Secara umum pengelolaan pendidikan akhlak mulia dalam proses pembelajaran dilakukan guru dengan menetapkan nilai-nilai akhlak mulia dan diintegrasikan dalam mata pelajaran yang diajarkannya dalam dokumen silabus dan RPP. Dalam kegiatan ekstra kurikuler berbentuk kegiatan halaqoh tarbawiyah atau mentoring keislaman, kegiatan organisasi santri, olahraga dan kepemimpinan. Pengelolaan sekolah berasrama menekankan pada pengelolaan SDM dan kepemimpinan yang mendorong partisipasi dan tanggung jawab seluruh komponen sekolah dalam mencapai tujuan pendidikan dan pembinaan akhlak mulia.

Pelaksanan pendidikan akhlak mulia melalui tahapan sebagai berikut: (a) meningkatnya keteladanan dan kepeloporan sivitas akademika sekolah dalam pelaksanaan nilai- nilai akhlak mulia, (b) meningkatnya pemahaman sivitas akademika terhadap kandungan ajaran Islam yang bersumber dari Alqur'an, (c) meningkatnya kegiatan salat berjamaah dilingkungan sekolah dan melaksanakan salatsalat sunnah, (d) menambah semaraknya kegiatan pengajian di lingkungan sekolah, yang meningkatkan nilai-nilai akhlak mulia, (e) Meningkatnya sivitas akademika dalam mengeluarkan zakat, infak dan sedekah, (f) meningkatnya syiar Islam dilingkungan sekolah dan kegiatan lain yang berdampak positif bagi lingkungan masyarakat sekitarnya, g) Hilangnya kemaksiatan, pelanggaran-pelanggaran dan perbuatan yang menyimpang dari ajaran Islam maupun aturan hukum negara, (h) meningkatnya insan mandiri yang religius dan mampu berdikari dalam pemberdayaan pendidikan, (i) meningkatnya kondisi, kebersihan, keindahan dan kenyamanan dilingkungan sekolah dan dalam kehidupan bermasyarakat, dan (j) Kokohnya persaudaraan sebagai modal utama bagi terciptanya kesatuan dan persatuan.

Evaluasi pembinaan pendidikan akhlak mulia di SMP BAS Tuban ditujukan pada program perencanaan dan pelaksanaan pendidikan akhlak mulia, dilakukan oleh guru/ pembimbing terhadap siswa berlangsung terus menerus terhadap seluruh aspek kegiatan dan kehidupan siswa di dalam sekolah dan asrama. Instrumen monitoring dan evaluasi berupa pedoman tata tertib, buku mutabaah dan renstra mampu menjadi alat pengumpul informasi ketercapaian program dan menjadi informasi berharga untuk refleksi dan program perbaikan selanjutnya.

Pengelolaan asrama SMP BAS (Boarding sistem) Tuban sebagai wahana implementasi pendidikan akhlak mulia dilakukan melalaui tahap-tahap pembuatan struktur organisasi yang mencerminkan tugas dan tanggung jawab, serta pembagian kerja pada tiap-tiap unit kegiatan yang ada. Sedangkan ruang lingkup kegiatan pengelolaan santri meliputi pengelompokan santri berdasarkan program kegiatan dan jenjang kelas. Pendidikan akhkak mulia siswa dilakukan melalui pendampingan dengan harapan dapat tertanam sikap rasa ingin tahu akan ilmu pengetahuan dan teknologi, memahami hak, kewajiban, sikap kemandirian, dan tanggung jawab. Mampu mengimplementasikan sikap dan pemahaman nilai-nilai akhlak mulia sebagai budaya 
dalam kehidupan sehari-hari. Baik melalui pengajaran (KBM), ekstra kurikuler, maupun kegiatan organisasi siswa sehingga diharapkan terbentuk jiwa kepemimpinan yang tangguh, jujur, disiplin, suka bekerja keras, dan bertanggung jawab.

Berdasarkan atas temuan hasil penelitian, pembahasan dan kesimpulan di atas, maka penulis menyampaikan rekomendasi terhadap pihak terkait sebagai berikut.

Bagi Sekolah: (1) perencanaan program pembinaan pendidikan akhlak mulia disamping dilakukan secara musyawarah di sekolah bersama dengan pihak yayasan, sebaiknya perencanaan dirumuskan bersama dengan konsultan ahli. Ini dimaksudkan agar indikator yang dijadikan penilaian keberhasilan benar-benar tepat mengukur dan menggambarkan ketercapaian program; (2) Kegiatan evaluasi selain dilakukan oleh pihak internal sebaiknya juga melibatkan pihak eksternal sehingga objektivitas hasil evalusi lebih baik. Ini dimaksudkan agar rutinitas pelaksanaan evaluasi dapat memperoleh penyegaran dan pencerahan dari asesor independen/ asesor luar. Dengan demikian rekomendasi bagi perbaikan program menjadi lebih terarah dan tepat; 3)Pengelolaan pendidikan akhlak mulia melalui kegiatan pembinaan dan pengelolaan sekolah harus diawali dengan pemodelan yang dilakukan oleh unsur pembina dan pengelola. Sehingga keberadaan siswa di asrama harus terasa nyaman dan bukan terasa beban dengan adanya berbagai aturan yang mengikat karena guru dan para pembimbing hadir menggantikan posisi orang tua yang mengayomi dan memberikan kasih sayang.

Bagi Guru, (1) tujuan pendidikan adalah membentuk manusia seutuhnya, menjunjung tinggi musyawarah, (demokratis) jujur, ramah, santun, dan religius; 2) Profesionalitas dan mutu guru harus dikembangkan untuk menjamin kemudahan dan ketersediaan; 3) Sarana prasarana dan lingkungan belajar yang nyaman perlu diusahakan. Sehingga siswa menjadi betah dan kerasan untuk belajar lebih baik; 4) Pengembangan metode dan media pendidikan harus melibatkan dan mengayomii semua kepentingan, sehingga mutu dan fungsi pemakaiannya terjamin. 4) Bagi Praktisi Pendidikan.

Kepala Sekolah. 1) Materi pendidikan yang diprogram hendaknya dilakukan secara seimbang antara aspek kognitif, afektif, mau- pun psikomotorik; (2) Peran kepala sekolah perlu lebih ditingkatkan, dengan otoritas sehingga dapat menggerakkan, dan mengawasi kegiatan dalam rangka mencapai tujuan pendidikan akhlak mulia.

Penelitian lanjutan, penelitian ini memfokuskan implementasi pelaksanaan pendidikan akhlak mulia di sekolah. Masih banyak yang perlu dikaji dan diteliti lebih jauh, yang berkaitan dengan nilai-nilai akhlak mulia, antara lain bagaimana pelaksanaan nilai-nilai akhlak mulia pada kalangan generasi muda, di keluarga, dan di lingkungan masyarakat.

\section{DAFTAR PUSTAKA}

Akdon. (2006). Strategic managemen for educational management. Bandung: Alfabeta.

Al-Abrasyi, M. A. (2003). Prinsip-prinsip pendidikan islam, terj. At-Tarbiyah alIslamiyah wa Falasifatuha, oleh Abdullah Zaky al-Kaaf. Bandung: Pustaka Setia.

Bryson, J. M. (2001). Perencanaan strategis bagi organisasi sosial. Yogyakarta: Pustaka Pelajar.

Djatnika, R. (1996). Sistem etika islami: akhlak mulia. Jakarta: Pustaka Panjimas.

Hadziq, A. (2005). Rekonsiliasi psikologi sufistik dan humanistic. Semarang: Rasail.

Ilyas, Y. (2014). Kuliah Akhlaq. Yogyakarta: Lembaga Pengkajian dan Pengamalan Islam (LPPI).

Katsir, I. I. I. (1420H). Tafsir al Qur-an al Adzhim. Daar thoyyibah li an nashr wa at tauzi'.

Marzuki. (2009). Prinsip dasar akhlak mulia pengantar studi konsep-konsep etika dalam islam. Yogyakarta: Debut Wahana Press \& FISE UNY.

Marzuki. (2011). Model pembentukan kultur akhlak mulia siswa SMP di Indonesia. Retrieved May 6, 2017, from https://marzukiwafi.wordpress.com/2011 /02/08/model-pembentukan-kulturakhlak-mulia-siswa-smp-di-indonesia/

Mujib, A. (2006). Ilmu pendidikan islam. (K. P. Media, Ed.). Jakarta. 
Mulkan, A. M. (1994). Paradigma intelektual muslim pengantar filsafat pendidikan islam dan dakwah. Yogyakarta: Gema Insani Press.

Munzir, A. (2012). Tuban bumi wali the spirit of harmony. Tuban: Pemerintah Daerah Kabupaten Tuban.

Republik Indonesia. Undang-Undang Dasar Negara Republik Indonesia Tahun 1945 (1945).

Robbins, S. P., \& Coulter, M. (2007). Manajemen (8th ed.). Jakarta: PT
Indeks.

Rusli, N., \& et al. (1993). Materi pokok akidah akhlak 1. Jakarta: Direktorat Jenderal Pembianaan Kelembagaan Agama Islam dan Universitas Terbuka.

Ulwan, A. N. (1990). Pendidikan anak dalam islam. Jakarta: Pustaka Amani.

Umaedi. (2004). Manajemen mutu berbasis sekolah/madrasah (MMBS/M). Jakarta: CEQM. 